\title{
A palavra de uma cidadã na tormenta revolucionária: o pensamento político de Olympe de Gouges
}

\author{
The word of a citizen in the revolutionary storm: \\ the political thinking of Olympe de Gouges
}

\author{
Marcela Prado Mendonça \\ Doutoranda em desenvolvimento \\ e meio ambiente- PRODEMA/UFS
}

\section{Marcelo de Sant'Anna Alves Primo \\ Doutor em filosofia pela UFBA e professor de Filosofia do Colégio de Aplicação da UFS}

Resumo: Nosso texto pretende refletir acerca dos modos de discurso e do alcance dos textos políticos de Olympe de Gouges. Em particular, vamos nos ater a três escritos da autora que, através de gêneros discursivos diferentes, permitem ver a sua produção plural e seu engajamento político no contexto da França revolucionária: 1) A Refléxion sur les noirs - 1788 - que apresenta sua experiência com a escravidão, a injustiça e o preconceito que a população negra sofria, mesmo que em uma época de ideias iluministas. Mais do que isso, ela critica a Comédie Française, a qual não permitia que uma de suas peças de teatro fosse representada ao público, já que continha uma contundente crítica à discriminação racial; 2) A Déclaration des droits de la femme et de la citoyenne - 1791 - que surgiu durante o momento em que as mulheres tinham seus próprios clubes políticos; 3) Por último, o panfleto Les 
trois urnes - 1793 - texto que desnuda o caráter autoritário do Estado jacobino pós-revolução e que levou Olympe a ser guilhotinada.

Palavras-chave: Olympe de Gouges; mulheres; revolução; política.

Abstract: Our text intends to reflect on the ways of discourse and the scope of the political texts of Olympe de Gouges. In particular, we will stick to three writings of the author that, through different discursive genres, allow us to see her plural production and political engagement in the context of revolutionary France: 1) The Refléxion sur les noirs - 1788 - which presents her experience with the slavery, injustice and prejudice that the black population suffered, even in an age of Enlightenment ideas. More than that, she criticizes Comédie Française, who did not allow one of her plays to be performed to the public, as it contained a blunt criticism of racial discrimination; 2) The Déclaration des droits de la femme et de citoyenne - 1791 - that arose during the time when women had their own political clubs; 3) Lastly, the pamphlet Les trois urnes - 1793 - a text that underscores the authoritarian character of the post-revolutionary Jacobin state and led Olympe to be guillotined.

Keywords: Olympe de Gouges; women; revolution; politics.

"Mulher, acorda! A força da razão faz-se ouvir por todo o universo; reconhece teus direitos."

Olympe de Gouges, Declaração dos direitos da mulher e da cidadã, "Pós-âmbulo".

\section{Introdução}

Tão há dúvida da radicalidade do discurso ${ }^{93}$ de Olympe de 1 Gouges no que concerne à emancipação das mulheres ou, no mínimo, à conscientização delas do papel engajado e decisivo que elas têm e desempenham na política e na sociedade. Encarcerada na Abadia de Saint-Germain-des-Prés e sendo guilhotinada em 1793, tal execução foi motivada pela sua

$93 \quad$ A respeito da radicalidade do discurso de Olympe através, por exemplo, da intertextualidade, ver SIESS, J., 2016. 
oposição ao império do Terror pós-revolucionário imposto por Robespierre e seus comandados. À época da aprovação da $D e-$ claração dos Direitos do Homem e do Cidadão pela Assembleia Nacional da França em 1789, teve-se a impressão de uma atmosfera democrática em que todos os homens gozariam dos mesmos direitos. Em consonância com o surgimento de clubes políticos de mulheres ${ }^{94}$, Olympe encara de frente os seus opositores jacobinos. Com seu espírito livre e insubmisso, lança mão de um discurso político que reivindica a igualdade, sendo um pressuposto crucial e incontornável para a defesa dos interesses da nação, colocando-a no mesmo nível dos magistrados e acima dos revolucionários. Originária da classe social chamada "terceiro estado", após ficar viúva muito jovem, começou a frequentar os salões literários e a escrever peças teatrais, panfletos revolucionários, entre outros. O conteúdo de seus textos, além de uma dura crítica à sociedade, tratavam da defesa do abolicionismo, da igualdade entre os sexos, da defesa dos filhos ilegítimos e da proposta de divórcio. Dessa maneira, sendo uma mulher ilustrada, frequentava os salões, discutia com filósofos, escrevia a serviço de seus ideais e lutas e publicava seus escritos assinando com o seu próprio nome, a despeito de toda misoginia que existia no "esclarecido" Século das Luzes. ${ }^{95}$

Embora no século XVIII, as personagens femininas proliferassem tanto na cena pública como na literária, ainda estavam sob a tutela masculina, desprovidas de persona civil e política, existindo juridicamente apenas através do pai, marido ou outro "responsável" e não possuíam seus direitos civis, políticos e profissionais reconhecidos. Segundo Cruz, "mesmo após 1789, com a criação de um novo espaço político de 'liberdade, igualdade e fraternidade', além da inegável e ampla participação feminina na Revolução Francesa, as mulheres não foram contempladas com direitos políticos" (2018, p. 28). O chamado Século das Luzes, devido à valorização da razão e a $94 \quad$ Clubes contra os quais os jacobinos se insurgiram para justamente afastar as mulheres da política.

95 Todavia, Amanda de Queirós Cruz lembra que "muitas de suas demandas estavam presentes em reivindicações de outros iluministas e em reivindicações anônimas, como por exemplo, a participação política feminina aparecia nos escritos de Condorcet e nos cahiers de doléance" (2018, p. 28). 
mudança de paradigmas que estabeleceu, foi um século caracterizado por grandes mudanças, mas que ainda possuía resquícios e preconceitos dos séculos passados. Um exemplo disso seria a situação paradoxal das mulheres que, não sendo vistas como citoyennes da república, não usufruíam dos mesmos direitos civis, políticos e trabalhistas concedidos aos homens. ${ }^{96}$ Eram encaradas como desiguais e "até inferiores por muitos homens considerados esclarecidos, ao mesmo tempo em que o discurso sobre igualdade universal se intensificava e progredia na Europa ilustrada" (Id. Ibid.) Dessa maneira, o entendimento herdado pelo século XVIII sobre as mulheres era marcadamente circunscrito por um discurso misógino, sendo legitimado sucessivamente por grandes autoridades do período, tais como teólogos, juristas e médicos. O comportamento masculino concernente às mulheres sempre foi paradoxal, oscilando entre a atração e a repulsão, entre a admiração e a hostilidade. O discurso que alertava sobre o perigo da mulher e que impregnou

Segundo Michèle Riot-Sarcey, "A primeira dificuldade surge no acontecimento maior da Revolução Francesa, que declara o indivíduo livre: desfeitas as ordens, os homens são devolvidos a suas individualidades múltiplas e à desigualdade de suas situações sociais, enquanto os representantes, recentemente reconhecidos como detentores provisórios da soberania do povo, procuram reconstituir uma soberania una e indivisível. Soberania em condições de reunir indivíduos semelhantemente livres. Assim, um dos primeiros cuidados dos revolucionários representantes é distinguir a multiplicidade dos homens da comunidade dos cidadãos, pois só os cidadãos eram passíveis de reconstituir a unicidade da soberania. Ainda assim, era preciso separar os cidadãos passivos dos cidadãos ativos, na medida em que o homem só era pensado livre em função daquilo que ele não era ou já não era mais, ou seja, do homem dependente. Como se a dependência do outro fosse a condição da liberdade de um. Esse respeito, o abade Siéyès é o mais explícito nos debates preparatórios à Declaração dos Direitos do Homem: 'Todos os habitantes de um país devem nele gozar do direito de cidadão passivo; todos têm direito à proteção de sua pessoa, de sua propriedade, de sua liberdade, mas nem todos têm direito a tomar parte ativa na formação dos poderes públicos, nem todos são cidadãos ativos. As mulheres, pelo menos no estado atual, as crianças, os estrangeiros, também aqueles que não contribuíssem em nada para Sustentar o estabelecimento público, não devem em absoluto influir ativamente na coisa pública'. Essa rigorosa precisão aos poucos se torna certeza necessária ao bem público. Esboça-se então a imagem do cidadão esclarecido em primeiro lugar e, por consequência, proprietário, com a qual se identificam todos os representantes sucessivos do soberano, mantido assim em sua indivisível unidade" (1994, p. 249). 
as mentalidades desde o final da Idade Média vinha da Igreja "e delineava a mulher como dotada de sexualidade e pecado, uma mistura de Eva e Satã" (Id. Ibid., p. 29). Posteriormente, ganha destaque o discurso oficial acerca da mulher produzido em meados da Idade Moderna por autoridades, cujos pilares eram o discurso dos teólogos, a ciência médica - que identificava a mulher como um sexo oriundo do masculino e imperfeito - e o parecer formal dos juristas, que se afinavam e sustentavam de comum acordo. Assim sendo, como situar os escritos de Olympe de Gouges nesse contexto? Mesmo lançando mão de um apelo patriótico sob a sua pena com um objetivo político determinado, deixa subentendido nas entrelinhas "um projeto que visa ao estabelecimento de uma outra relação entre os dois sexos, à instauração da igualdade" (SIESS, 2005, p. 10). Mais do que isso, tal projeto nos leva a pensar em que medida e até que ponto a autora subverte o discurso político dominado pelos homens para colocá-lo a serviço de seus próprios fins, reivindicar os direitos da mulheres e propagar e defender a igualdade entre os sexos e outras causas que ela defendeu nos três escritos de Olympe escolhidos para este artigo.

\section{A crítica ao preconceito racial e à escravidão na Refléxion sur les noirs}

Em 1788, Olympe de Gouges redige a Réflexion sur les noirs. Com ideias abolicionistas, a autora pensa a condição dos escravos negros no século XVIII, onze anos antes da Revolução Francesa, em um contexto de profusão do ideário iluminista, evidenciando que os ideais de liberdade, igualdade e fraternidade ainda estavam longe de serem alcançados. ${ }^{97}$ Temática já abordada em 1783 com a sua peça teatral Zamora et Mirza ou l'Heureux Naufrage e que inaugura o ingresso de Olympe na literatura e que já mostra o seu engajamento político. A despeito de um clima de liberdade da palavra reinante nos salons e que ao teatro era inescapável ser objeto de debate, tema do preconceito racial era um assunto delicado mesmo no seio de um $97 \quad$ Só para situarmos, o decreto de abolição da escravatura nas colônias surge em 1794, sendo posteriormente restabelecido por Bonaparte em 1802 e definitivamente abolido em 1848. 
século "iluminado" e ainda mais quando a respectiva crítica da escravidão negra sai do punho de uma mulher. Ao final do prefácio da edição de 1792 - a última versão do texto - ela diz com todas as letras que o escreveu a peça para justifica-la a seus detratores, "que os odiosos Colonos tinham proscrito e apresentado como uma obra incendiária" (2014, p. 8)..$^{98}$ O conteúdo anti-escravagista da peça foi apresentado pela primeira vez em que, na história do teatro, foram escolhidos como personagens principais escravos negros, tanto no nível dos decoros e costumes, como no nível das maquiagens e dos figurantes, aspectos que deram uma verdadeira coloração local à representação cênica da peça de Olympe. Aí ela toma partido publicamente pela abolição da escravidão, traçando "em algumas linhas todos os vergonhosos preconceitos sobre o racismo, fundados sobre a crença na maldição divina que a Igreja católica jamais colocará fim" (BLANC, 2014, p. 90).

Logo no início da Réflexion, Olympe afirma com todas as letras: "sempre me interessei pelo destino deplorável da raça negra" (2018[1788], p. 284. ${ }^{99}$ À medida que o seu entendimento sobre as coisas mundanas se desenvolvia, ocorreu a primeira vez em que viu uma mulher negra, levando-a a refletir e questionar-se sobre a sua cor. Perguntas feitas a outrem não colocaram termo à sua curiosidade e intelecto, já que só ouvia como resposta que as pessoas negras eram selvagens, castigadas pelos céus. Quanto mais crescia, Olympe entendia que não era de forma alguma de ordem natural que a escravidão era infligida aos negros e que a única causa dessa injustiça era o poder e os anseios particulares dos brancos: "Na medida em que crescia, percebi claramente que o preconceito e a força as condenavam àquela escravidão terrível, na qual a Natureza não participava de forma alguma; e que os poderosos e injustos interesses

$98 \quad$ Trecho retirado de uma conferência proferida por Geneviève André-Acquier, em razão de uma homenagem à Olympe de Gouges na cerimônia de entrega de diplomas aos nomeados e promovidos na ordem das Palmas Acadêmicas, em 17 de abril de 2014, na prefeitura de Montauban. Disponível em: http://web.ac-toulouse.fr/automne_modules_files/pDocs/public/ r26109_61_olympe_de_gouges_et_la_question_de_lesclavage_des_noirs.pdf 99 Utilizo aqui a tradução feita por Jasmim Sedie Drigo e Nádia Carrasco Pagnossi, cotejando-a com a edição original francesa de 1788. 
dos brancos eram os únicos responsáveis pelo fato" (Id. Ibid.) Convicta sucessivamente da verdade sobre a condição dos escravos, Olympe inspira-se em tal episódio para a sua estreia nos espetáculos teatrais franceses com uma peça surgida de sua imaginação. Se o interesse despertado nos homens pelo destino dos escravos os levaram a dispender esforços para aliviarem o peso da escravidão nos negros, contudo, nenhum permitiu que eles representassem em um palco a sua própria condição, com suas indumentárias e a sua cor, como ela tinha em mente e se não esbarasse na proibição estipulada pela Comédie Française:

Convencida por um longo tempo dessa verdade e dessa terrível situação dos escravos, inseri sua história na primeira peça que surgiu da minha imaginação. Muitos homens se interessaram pelo destino dos escravos e se esforçaram para aliviar seu fardo, porém nenhum pensou em deixá-los subir ao palco com suas roupas típicas e sua cor como eu planejava fazer, se a Comédie Française não tivesse se oposto (Id. Ibid.)

Colocando em segundo plano a sua peça e a recepção da mesma pelos especialistas da Comédie e pelos espectadores em geral, Olympe se ocupa com uma questão: em relação à situação da escravidão negra "quando nos ocuparemos em mudar essa realidade, ou ao menos tentar amenizá-la?" (Id.Ibid., pp.284-285). Tais indagações acerca de qual maneira é possível tirar os negros de sua situação deplorável de escravidão começaram a enfurecer os proprietários coloniais ${ }^{100}$. Contando entre as raras mulheres da Société des Amis des Noirs, foi acusada por seus detratores de "donzela escritora de maus romances sobre o Congo" (BLANC, op.cit., p. 91). Para a girondina, as pessoas são iguais em todos os lugares e toda a desgraça promovida pela escravidão começou quando ela se tornou um comércio, traduzida pela ganância e avidez por ganho nas ilhas mais inóspitas. Os colonos europeus, movidos pela cobiça do que pode-

$100 \quad$ Segundo Olivier Blanc, "Esses primeiros movimentos filantrópicos terminaram inquietando seriamente os proprietários coloniais. Em 1789, para se opor aos esforços dos Amigos dos Negros, eles formaram um clube fazia suas reuniões no hotel de Massiac, na praça das Vitórias, em Paris. Toda a sociedade crioula, muito poderosa, aí se encontrava periodicamente para exercer uma espécie de pressão sobre a Assembleia Nacional que, ela mesma, contava muitos deputados proprietários coloniais" (2014, pp.90-91). 
ria ser extraído nos lugares mais remotos, mudavam completamente o curso das coisas onde pisavam. Dessa maneira, "pais passaram a repudiar seus filhos, filhos a sacrificar seus pais, irmãos a brigar, e os derrotados foram vendidos como gado no mercado. À que me refiro? Que a escravidão se tornou um comércio nos quatro cantos do mundo" (GOUGES, 2018[1788], p. 285). ${ }^{101}$ À luz dessa constatação, por exemplo, lembremos que em 1789, a colônia francesa das Índias Ocidentais de São Domingos respondia por dois terços do comércio exterior francês, constituindo-se como o maior mercado individual para o tráfico de negros da Europa. Era um dos motores da economia à época, a maior colônia do planeta, o orgulho francês que atraía os olhares invejosos de outras nações imperialistas e a sua estrutura era amparada pelo labor de quinhentos mil escravos. ${ }^{102} \mathrm{O}$ espanto de Olympe a respeito de pessoas serem

$101 \quad$ Holbach, em 1772, n’A moral universal, já desferia duras críticas ao tráfico de escravos e às leis que permitiam esse tipo de "comércio": "Assim a razão humana, desenvolvendo-se com o tempo, curou pouco a pouco as nações da sua bárbarie e as conduziu a alguns usos mais equitativos, mais conformes à moral e a interesse do gênero humano. Essa moral clama a todos os habitantes do mundo que, ricos ou pobres, poderosos ou fracos, ditosos ou desgraçados, eles são da mesma espécie e têm direitos iguais à equidade, à beneficência e à piedade de seus semelhantes. Porém, sua voz não se fez ouvir por esses mesmos europeus, quando sua avidez os transplantou para um novo mundo. Vós os vedes, nessas regiões, comandar como verdadeiros tiranos alguns negros desgraçados, que um comércio odioso compra como vis animais para revender a senhores impiedosos que lhes fazem sentir as crueldades e os caprichos dos quais a insolência, a impunidade e a avareza podem tornar capaz. Esse tráfico abominável é, no entanto, autorizado pelas leis de nações que se dizem humanas e civilizadas, ao passo que um sórdido interesse faz que elas, evidentemente, ignorem os direitos mais sagrados da humanidade" (2014, III, vi, p.743). Em um tom ainda mais radical, Frantz Fanon, em Os condenados da terra, afirma: "Essa opulência europeia é literalmente escandalosa, pois foi construída sobre as costas dos escravos, alimentou-se do sangue dos escravos, vem em linha direta do solo, e do subsolo desse mundo subdesenvolvido. O bem-estar e o progresso da Europa foram constituídos com o suor e os cadáveres dos negros, dos árabes, dos índios e dos amarelos. Isso, decidimos não esquecer jamais" (2005, pp. 122-123).

102 Contudo, em seu livro Os jacobinos negros: Toussaint LOuverture e a revolução de São Domingos, C. L.R. James comenta: "Em agosto de 1791, passados dois anos da Revolução Francesa e dos seus reflexos em São Domingos, os escravos se revoltaram. Em uma luta que se estendeu por doze anos, eles derrotaram, por sua vez, os brancos locais e os soldados da monarquia 
comercializadas é no sentido de os brancos não conseguirem entender que eles são iguais aos negros a despeito de sua cor, e é nessa variedade que a natureza mostra toda a sua perfeição. Atentar contra essa pluralidade racial é querer ir contra à sua obra. Assim como a vasta diversidade de espécimes de animais, plantas e minerais diferentes que a Natureza produziu, em relação à cor das pessoas não seria diferente. Assim, "Por que o dia não discute com a noite, o sol com a lua, ou as estrelas com o céu? Tudo é diferente, é diverso, e é nisto que reside a beleza da Natureza. Por que então destruir sua obra?" (2018[1788], p. 285) A humanidade sendo o que há de mais belo originado pela natureza, não acusam de bárbaras as raças que exploram os brancos, e estes, por sua vez, em relação aos negros, são "igualmente cruéis com pessoas cujo único meio de resistência é a submissão" (Id.Ibid.).

Nesse sentido, Olympe chega talvez ao ponto nevrálgico do conteúdo revolucionário da Réflexion, a saber, quando a submissão começa a enfraquecer, se eleva o sentimento de revolta, de vários tipos, uma vez que esse sentimento explode dentro do escravo e leva-o a agir. É inadmissível que colonos, sustentado pelo trabalho de seus escravos, os castiguem sem parar, não pensando minimamente em um tratamento melhor para com eles. ${ }^{103}$ Nesse sentido, é permitido pensar a respeito de mudar o seu destino, melhorar suas condições de vida e

francesa. Debelaram também uma invasão espanhola, uma expedição britânica com algo em torno de sessenta mil homens e uma expedição francesa de semelhantes dimensões comandada pelo cunhado de Bonaparte. A derrota da expedição de Bonaparte, em 1803, resultou no estabelecimento do Estado negro do Haiti, que permanece até os dias de hoje. Essa foi a única revolta de escravos bem-sucedida da História, e as dificuldades que tiveram de superar colocam em evidência a magnitude dos interesses envolvidos. A transformação dos escravos que, mesmo às centenas, tremiam diante de um único homem branco, em um povo capaz de se organizar e derrotar as mais poderosas nações europeias daqueles tempos é um dos grandes épicos da luta revolucionária e uma verdadeira façanha" (2010, p. 15).

103 Holbach argumenta na mesma linha de raciocínio: "Essa humanidade deveria fazê-las sentir que os homens negros são homens, sobre cuja liberdade os homens brancos não têm o direito de atentar, mas, pelo menos, deveriam tratar com bondade, quando o destino os submete ao seu poder" (2014, III, vi, p. 743). 
fazer com que eles não usufruam mal da liberdade que lhes for concedida (2018[1788], p. 286). Ironicamente, Olympe afirmando não entender nada de política, argumenta que alguns preveem que uma liberdade mais ampla colocaria em pé de igualdade os negros e os brancos, e os primeiros sendo, a partir de então, donos de seus próprios destinos, poderiam eles mesmos comandar as suas vontades empenharem-se mais em seus ofícios. Não seriam mais vítimas da intolerância, e tendo os mesmos direitos como os outros, tornar-se-iam mais sábios e humanos (Id. Ibid.). Dessa maneira, retratando de uma forma corajosa a situação dos negros nas colônias, ela o fez no pior momento, a saber, quando havia uma grande diatribe promovida pelos proprietários coloniais contra os defensores da abolição da escravidão. Inspirando-se no texto de Olympe, poderíamos retornar ao exemplo de São Domingos, mas agora quando obtiveram a sua independência em 1803, processo iniciado em agosto de 1791 - três anos depois da publicação da Réflexion quando os escravos movidos pelos rumores da Revolução Francesa, rebelaram-se contra seus opositores brancos e contra os soldados das tropas à mando do regime monárquico francês. Todavia, se os escravos haitianos se inspiraram na Réflexion de Olympe para obterem a sua alforria, isso é uma outra história. O que intentamos mostrar é que, à luz da sua entrada inaugural na Comédie Française com uma peça crítica ferrenha do tráfico negreiro e, mesmo entendendo que suas apreciações, boas ou más, sejam devidas ao acaso, Olympe, através do teatro, pôde manifestar a sua sensibilidade e o seu apoio incondicional à abolição da escravatura: "Mais do que ninguém, devo me interessar pelo destino desses desafortunados Negros, porque faz cinco anos desde que escrevi uma peça baseada em sua história trágica" (2018[1788], p. 286).

\section{Direitos e deveres iguais a ambos os sexos na Déclara- tion des droits de la femme et de la citoyenne}

Em 1791, Olympe ousadamente redige uma Declaração dos Direitos da Mulher e da Cidadã, considerada um escândalo saído da pena de uma mulher vista como contrarrevolucioná- 
ria, à medida que subverte o discurso político de dominação masculina utilizando-o para seus próprios fins. Tal declaração, motivada pela reivindicação de igualdade entre ambos os sexos, demonstrou os limites das atribuições e garantias de cidadania a ambos os sexos no seio da Revolução. Iniciando o texto com os fatores que foram causadores de calamidades públicas e da corrupção do governo, a girondina resolve mostrar a todos, republicanamente, "uma declaração solene, os direitos inalienáveis e sagrados da mulher" (1791, p. 6). Mas quais foram os antecedentes da redação da Declaração? Olympe escreve uma epístola intitulada À rainha, na qual desenvolve o seu argumento político destinando-se a Marie-Antoinette. Afirmando ser "pouco afeita à linguagem dos reis" (1791, p. 1), mostra tomar partido do povo estando à frente desse movimento. Segundo Siess, "o ethos da locutora desvela a cidadã que estende a mão à esposa do monarca para lhe mostrar o bom caminho a seguir, além de guiar o próprio rei nesse caminho" (2016, p. 146). Eloquência humilde e direta à Rousseau - pelo qual não esconde o apreço - que permeia o caminho a ser seguido, reportando-se primeiro à rainha, aos franceses e depois às mulheres. Colocando-se mesmo à altura da realeza, Olympe, em meio à tirania promovida sumariamente pelo projeto político revolucionário, entende que contribui para a mudança de mentalidade em relação ao porvir dos novos tempos. Em um tête-à-tête com a sua destinatária, Madame de Gouges tenta fazer com que a rainha esqueça a sua figura de perseguida e que se empenhe no dever de trazer de volta ao seio da nação os que dela se afastaram e tornaram-se seus inimigos ${ }^{104}$. A sua figura na esfera privada agora é completada por outra que remete à esfera pública, a saber, a da "rainha mediadora que têm deveres para com a nação" (SIESS, 2005, p. 14). Em nome dos direitos das mulheres, Olympe entende que Marie-Antoinette tem um papel fundamental, já que "não foi o acaso que a elevou a um

$104 \quad$ Para Siess, "[...]la figure de la reine persécutée appartient au passé ; au moment où Olympe lui écrit, c'est la réaction de Marie-Antoinette qui constitue l'enjeu. Lépistolière formule donc avec force ses attentes à l'égard de sa partenaire: comme toute mère et épouse, Marie-Antoinette a le devoir de ramener au sein de la famille les membres qui s'en sont éloignés et risquent de se tourner contre elle" (2005, p. 14). 
lugar iminente, de dar peso à desenvoltura dos Direitos das Mulheres e de acelerar o seu sucesso" (AR, 1791, p. 2). Dessa maneira, podemos perceber os dois objetivos da epístola à rainha: instiga-la a sustentar a causa das mulheres e fornecer à Olympe as bases para uma nova Declaração dos direitos. $\mathrm{O}$ apelo político agora dá lugar à exigência de trabalhar na instauração da igualdade entre mulheres e homens.

Composta de dezessete artigos breves, a Declaração tem por base a supracitada Declaração dos Direitos do Homem e do Cidadão, consumada em 1789, mas suscetível de ser mudada decisiva e substancialmente em vários pontos sob a pena de Olympe. Por exemplo, no artigo I, "a Mulher [e não o homem] nasce livre e permanece igual em direitos" (1791, p. 7, grifo nosso). No artigo XI consta:

A livre comunicação dos pensamentos e das opiniões constitui um dos direitos mais preciosos da mulher [e não somente do homem], dado que esta liberdade garante a legitimidade dos pais em relação aos filhos. Toda cidadã [e não somente o cidadão] pode, portanto, dizer livremente: eu sou a mãe de um filho que lhe pertence, sem que um preconceito bárbaro a force a esconder a verdade; sob pena de responder pelo abuso dessa liberdade nos casos estabelecidos pela lei (Ibid., p. 9-10, grifos nossos).

No artigo XII, “a garantia dos direitos da mulher e da cidadã necessita de uma utilidade maior; tal garantia deve ser instituída para vantagem de todos, e não para a utilidade particular daqueles a quem ela foi confiada" (Ibid., p. 10). No artigo III talvez esteja uma das mudanças mais importantes em relação à Declaração de 1789, quando Olympe afirma a necessidade de uma dupla Assembleia: "O princípio de toda soberania reside essencialmente na Nação, que nada mais é que a reunião da mulher e do homem: nenhum corpo, nenhum indivíduo pode exercer autoridade que não emane expressamente deles" (Ibid., p. 7, grifo nosso). Tais exemplos ilustram a prioridade dada às mulheres no conteúdo do texto, não mais podendo serem deixadas de fora do espaço público, como afirmara Rousseau que, paradoxalmente, é a fonte filosófica inspirada de Olympe.

Uma das referências da Declaração é o Segundo Discurso do filósofo de Genebra - 1755 - no qual ele reflete sobre a 
origem e os fundamentos da desigualdade entre os homens. ${ }^{105}$ Tal obra, que dará todo o fundamento antropológico do discurso defensor dos direitos das mulheres de Olympe, servirá justamente para subvertê-lo" ${ }^{106}$, à luz do primeiro artigo: "A Mulher nasce livre e permanece igual ao homem em direitos. As distinções sociais só podem ser fundamentadas no interesse comum" (DD, 1791, p. 7). É sabido que no Segundo Discurso, Rousseau estabelece a oposição entre o homem natural e o social, mostrando que este último se corrompeu sucessivamente à medida que se aperfeiçoou cada vez mais. A natureza, que não mente de forma alguma, mostra de forma evidente que os homens são iguais por natureza, logo, atribuindo-lhes direitos incontestáveis (SIESS, 2016, p. 151). Nesse sentido, como Rousseau, Olympe relaciona antropologia e política, destacando que, entre os direitos do homem, a igualdade se sobressai. Contudo, há profundas diferenças entre os argumentos de um escrito e outro seja na conclusão, seja no que tange à orientação argumentativa. Em última instância, a natureza permite negar a superioridade do homem.

Insistindo mais um pouco nos ecos da obra de Rousseau nos argumentos da Declaração de Olympe, vemos lá no artigo VI a noção de "vontade geral"107, tão cara ao filósofo de Genebra, vontade não da soma quantitativa dos membros do corpo político, mas concernente ao que todos querem em co-

$105 \quad$ Logo no parágrafo inaugural do Segundo Discurso, assim consta: "É do HOMEM que devo falar e a questão que examino me diz que vou falar a homens pois não se propõem questões semelhantes quando se tem medo de honrar a verdade. Defenderei, pois, com confiança, a causa da humanidade perante os sábios que me convidam a fazê-lo e não ficarei descontente comigo mesmo se me tornar digno de meu assunto e de meus juízes" (1987-88, p. 39, destaque em maiúsculas de Rousseau).

106 Olympe alude ao escrito de Rousseau em um texto chamado $A$ felicidade primitiva do homem.

107 "A lei deve ser a expressão da vontade geral; todas as cidadãs e cidadãos devem colaborar pessoalmente ou por seus representantes, para a sua formação; ela deve ser igual pra todos: todas as cidadãs e todos os cidadãos, sendo iguais frente a ela, devem ser igualmente admitidos a todas as dignidades, postos e empregos públicos, de acordo com sua capacidade, e sem qualquer distinção a não ser por suas virtudes e seus talentos" $(D D, 1791$, p. 8 , grifos nossos). 
mum para a fundação e manutenção de um Estado ${ }^{108}$. E no artigo IV a questão dos direitos naturais se apresenta, como no Segundo Discurso e no Do Contrato Social, atrelada às noções de liberdade e de justiça, mas

A liberdade e a justiça consistem em restituir tudo que pertence a outrem. Sendo assim, o exercício dos direitos naturais da mulher não tem outros limites senão a perpétua tirania que o homem lhe impõe; estes limites devem ser reformados pelas leis da natureza e da razão $(D D, 1791$, p. 8 , grifo nosso).

Contudo, salta à vista que a inspiração de Rousseau fica para trás quando o exercício dos direitos naturais da mulher e não mais unicamente do homem ${ }^{109}$ - fazendo com que ela se torne sujeito de direito par excellence. ${ }^{110}$ Nesse sentido, não é possível argumentar que o termo "homem" na Declaração de 1789 seja equivalente à "humanidade" como um todo, pois as mudanças feitas por Olympe em seu texto foram feitas justamente para mostrar o embate entre homens e mulheres, do qual ela mesma foi vítima subindo ao cadafalso. Nesse sentido, a própria concepção de natureza defendida por Rousseau no Segundo Discurso parece se voltar contra ele, pois agora "é a mulher que ocupa o lugar legítimo por natureza" (SIESS, 2016, p. 152). O suposto direito natural do homem seria, na verdade, o direito do mais forte imposto sucessivamente no decorrer dos tempos, por meio de atos tirânicos que promoveram a transformação de um mundo natural em um mundo normatizado

108 "Há comumente muita diferença entre a vontade de todos e a vontade geral. Esta se prende somente ao interesse comum; a outra, ao interesse privado e não passa de uma soma das vontades particulares. Quando se retiram, porém, dessas mesmas vontades, os a-mais e os a-menos que nela se destroem mutuamente, resta, como soma das diferenças, a vontade geral" (ROUSSEAU, 1987, II, iii, p. 47).

109 Rousseau afirma no Segundo Discurso: "Essa ignorância da natureza do homem é que lança tanta incerteza e obscuridade sobre a definição verdadeira do direito natural, pois, como diz, o Sr. Burlamaqui, a ideia do direito e, mais ainda, a ideia do direito natural, são evidentemente ideias relativas à natureza do homem" (1987-88, p. 33, destaques nossos).

110 Substituindo o que asseverava o mesmo artigo IV da Declaração dos Direitos do Homem e do Cidadão, de 1789: "desse modo, o exercício dos direitos naturais de cada homem tem como únicas barreiras as que asseguram aos outros membros da sociedade o gozo dos mesmos direitos". Ver SIESS, 2016, p. 151. 
por regras civis. Sendo necessária ser revista essa desigualdade entre os sexos pelas leis da natureza e da razão, o artigo V diz: "As leis da natureza e da razão proíbem todas as ações nocivas à sociedade; tudo que não é defendido por tais leis [...] não pode ser impedido, e ninguém pode ser constrangido a fazer aquilo que elas não ordenam" ( $D D, 1791$, p. 8). Podemos depreender do conteúdo do artigo citado que o direito de igualdade é levado às últimas consequências, servindo plenamente à causa das mulheres, mesmo o termo igualdade sendo positivo em determinados artigos da Declaração e em outros adquirindo um cunho negativo. ${ }^{111}$

\section{A denúncia do autoritarismo jacobino no panfleto Les trois urnes}

Olympe de Gouges já se destacara no final da década de 1780 , como autora de várias peças inspiradas em questões políticas imediatas. Com o status de cidadão que a Revolução Francesa concedeu a ela, abdicou plenamente do seu direito de refletir acerca das questões mais importantes da época. A sua última declaração pública estando livre foi o panfleto Les trois urnes. É uma grande folha de fólio, impressa apenas de um lado, o título, impresso em maiúsculas grandes e negritas, enquanto a impressão do texto em duas colunas verticais. $\mathrm{O}$ mais impressionante e muito chamando a atenção para si mesma, como uma publicação não-oficial, é o papel de cores vivas em que é impresso. ${ }^{112} \mathrm{O}$ panfleto trata da necessidade de um plebiscito nacional para decidir que forma de governo é a mais favorável pelo povo francês. A escolha se dá entre uma república unitária, um sistema federal ou uma monarquia constitucional. A escrita é urgente, mas a identidade autoral adotada, quando slogans severos e comícios gritados eram corriqueiros à época. Luís XVI fôra guilhotinado em 21 de janeiro de 1793, Marie-Antoinette estava encarcerada, os deputados girondinos

$111 \quad$ O maior exemplo disso seria no artigo IX: "Com toda mulher declarada culpada, deve ser exercido todo rigor da lei" ( $D D, 1791$, p. 9).

112 Disponível em: https://blogs.bl.uk/european/2013/11/olympe-de-gouges-and-les-trois-urnes.html 
da Convenção Nacional, com quem Olympe de Gouges simpatizava politicamente, sucumbiam e a sua prisão havia sido ordenada em 13 de junho de 1793, sendo que era legal a pena de morte. Além disso, a França foi assolada por inimigos externos, a Convenção Nacional não admitiu nenhum desafio ao seu poder soberano e sua facção dominante - os jacobinos - deixou clara a estrutura ideológica de seu Estado inegociável em todos os decretos emitidos: a República, indivisível. Os argumentos de Olympe sobre a estrutura do Estado eram mais moderados. A publicação desses argumentos em Les Trois Urnes foi excepcionalmente corajosa, mas que a levou à morte. Ela foi rapidamente identificada como a autora do cartaz, presa e julgada perante o Tribunal Revolucionário sob acusação de sedição em 2 de novembro de 1793, sendo o conteúdo do cartaz usado como parte das evidências contra ela. ${ }^{113}$ Considerada culpada, ela foi decapitada na guilhotina no dia seguinte, sendo que Maria Antonieta, os deputados girondinos e muitos outros tiveram o mesmo fim.

Em 1793, o novo patriotismo francês, fundado sobre o amor de uma pátria libertada do despotismo sob todas as suas formas, substituíra a lealdade do Ancien Régime. Os soldados revolucionários representavam um povo livre que trava embate somente contra os tiranos para defender a causa dos povos e que "dá às nações seus direitos, sua majestade e sua primeira energia" (BLANC, 2014, p. 191). Entretanto, a tirania jacobina não tardou a se mostrar politicamente através de um autoritarismo revolucionário, não sendo permitido aos franceses elegerem qual forma de governo seria mais conveniente à nação. Diante deste contexto político, sempre consciente dos próprios meios expressivos da própria capacidade desenvolta de expor

$113 \quad$ Sobre os antecedentes da morte de Olympe, ver o belo romance de Maria Rosa Cutrufelli, Eu vivi por um sonho: os últimos dias de Olympe de Gouges, defensora dos direitos da mulher. A respeito do conteúdo do panfleto, vejamos um dos diálogos de Olympe contra o seu delator, Fouquier-Tinville: "[FT] - Que imaginação, senhora! Pretende sustentar que homens que pensam a questão de modo diverso uns dos outros poderiam reunir-se em um único lugar para depositar seus votos numa urna? Como pode crer que isso aconteceria de maneira pacífica? Não lhe parece uma ideia perigosa? [OG] - As urnas são a alternativa à revolta armada" (2009, p. 90). 
as próprias ideias usando a palavra, sobretudo escrita, Olympe no panfleto Les trois urnes "acentua e declara a tendência à provocação, ao protagonismo e à autoreferência" (GRASSI, 2017, p. 186). Ideologicamente não aceitava a ideia de igualdade e liberdade defendida por seus colegas, que apoiavam uma igualdade somente entre os homens, excluindo o sexo feminino, o que para ela não constituía uma igualdade real. Passou então a redigir manifestos que defendiam a inclusão das mulheres na Revolução e na construção de um novo governo. A autora se insurgia também contra Jean-Paul Marat e Maximilien Robespierre, principais expoentes do partido Jacobino, que instaurou o Reino do Terror em 1792. Ela acusava ambos por terem sido os principais responsáveis pelos massacres de setembro de 1793, que somaram aproximadamente 2.000 mortes. Além disso, acusava os Jacobinos de aspirarem ao autoritarismo em vários de seus escritos, valendo-lhe uma denúncia ao Clube dos Jacobinos. Estima-se que o Reino do Terror tenha feito aproximadamente 17.000 vítimas, a maioria delas guilhotinadas, e todas por razões políticas. Em março de 1793, entrou em vigor uma lei que permitia a repressão de escritos que defendessem os princípios republicanos, e era exatamente o que fazia seu manifesto Les Trois Urnes ou Le Salut de la Patrie, obra de caráter federalista e girondino.

Então vamos ao texto propriamente dito. Abrindo o texto por meio de um personagem chamado Toxicondindronn, cujo significado botânico remete a uma planta venenosa, e essa metáfora sutil se relaciona ao autoritarismo jacobino como um verdadeiro tóxico à nação francesa, mostrando que em toda parte existe a estupidez humana e seus crimes mais atrozes. Em todos os governos extremos, o bem sempre nasce do mal, o que constituiria "a essência das revoluções, para regenerar governos com o excesso de sua depravação. Francês: pare, leia. Tenho-lhe muitas coisas para contar" (1793a). Segundo Olympe, o mundo nem começou no paraíso com Adão e Eva muito menos acabou com a Revolução Francesa. Esta, mantendo a corrupção característica do Ancien Régime, faleceu justamente no momento de sua regeneração. Contudo, a tripartição da França parece mostrar que as grandes revoluções também o são 
em crimes, ferindo a dignidade de um verdadeiro republicano. Para Olympe, é preciso olhar realmente nos olhos do inimigo e perceber que, apesar de o tirano estar morto, os seus excessos ainda permanecem no seio da república, sendo preciso enfrenta-los: "Qual é o motivo de sua dissidência, francês? A morte do tirano. Bem, ele está morto! Com o seu todas as partes têm que cair, e seus excessos criminosos me lembram, apesar de mim, da imagem grandes revoluções: submeto aos seus olhos novamente, tenha a coragem de olhar para ele" (1793a).

Citando vários episódios históricos, Olympe argumenta que em todos esses momentos sempre haverá a oportunidade de derrubar tiranias que impedem o bom exercício dos governos e a sua conservação, sempre tendo como fim último a paz e felicidade universais. Os homens por natureza são iguais e se fosse o caso de, dentre eles, surgir um líder, sê-lo-ia para "para vigiá-los incessantemente sobre a felicidade deles, e não para que isso criasse em torno de si, prevalecendo sobre meus direitos sagrados" (Ibid.) Nesse sentido, um líder não pode estar à frente de uma nação para somente obter privilégio à custa de quem o elevou ao poder, como um parasita que suga todas as forças de um Estado em prol de seus anseios particulares. ${ }^{114}$ Através da fala do personagem do panfleto, Olympe discorre que Toxicodindronn, cansado, venceu os opositores sacrílegos, reabilitando os direitos do francês e que vai percorrer o globo para acabar de exterminar os opositores querendo "purificar a Revolução Francesa, como um licor que, depois de muito tempo coberto pelo lixo de todas as mentes que o criaram, torna-se um néctar, agradável e saudável" (Ibid.) A França estando dividida em três, são três poderes lutando entre si e, se não porem termo a suas contendas recíprocas, matarão uns aos outros. $\mathrm{O}$ verdadeiro republicano quer que eles vivam em harmonia,

114 "Não sei que crime é esse me fazendo dizer o que nunca pensei, os padres roubaram metade da fortuna pública, nem como os nobres conseguiram erguer palácios, ao lado do humilde chalé, e insultar, com pompa e sua devassidão, o lavrador indigente, o fazendeiro virtuoso que regava com sua fúria e sua rasga o campo que alimentava aqueles homens orgulhosos e vaidosos. "Oh! Quão grato você é pela honestidade do agricultor, guiado pela natureza simples! Sob sua aparência áspera, seu coração é generoso. Enterrado abaixo chão lamacento...é ouro" (1793a). 
não permitindo que o inimigo estrangeiro, aproveitando-se da França fragmentada, a invada apagando o seu esplendor.

E quem fará escolher a melhor forma de governo para uma nação acometida pela corrupção revolucionária? Como se pronunciar sobre um governo que deve ser submetido a todas as opiniões? Olympe faz o seu apelo: que os franceses escolham por si mesmos "e decidam qual governo é mais adequado ao seu caráter, seus costumes, seu clima, de modo que para eles a revolução é para sempre a escola dos tiranos, e não a escola dos povos" (1793b). Não é mais possível recuar dessa empreitada, a saber, a da instauração de um governo sadio e sólido, austero nas leis contra as torturas e guilhotinadas, atrocidades resultantes das opiniões divergentes de um governo tripartido. Dessa maneira, todos devem se pronunciar livremente sobre qual forma de governo a ser adotada. Olympe solicita à Convenção que restabelecesse o decreto que suspenda as armas para deixar o povo mais tranquilo para decidir entre as formas de governo propostas. Por sua vez, cada departamento formaria a convocação das assembleias primárias, "sendo colocadas três urnas do presidente da assembleia e em cada uma delas esse registro: governo republicano, uno e indivisível: governo federativo; Governo monarquista" (1793b). A escolha será livre e individual de cada governo e cada eleitor com o seu respectivo voto em mãos. O governo que conseguir a maioria dos votos comemorará a sua vitória em um festival cívico e "o universo gritará, tão espantado há quanto tempo está atento às dissensões da França: 'Os franceses são invencíveis!'” (1793b). E quem tem realmente apreço à pátria e à igualdade, viveria com prazer em "um governo verdadeiramente republicano; mas, como você sabe, esse governo quer ser governado por homens virtuosos e desinteressados" (1793b). O final dessa história todos sabemos: devido ao teor anti-jacobino do seu panfleto Les trois urnes, em dois de novembro de 1793, seus companheiros girondinos foram executados. Olympe foi interrogada sem a presença de um advogado. Ao ser condenada à pena de morte, ela declarou que estava grávida, mas um dos acusadores públicos do Tribunal não acreditou nela. No dia 3 de novembro, Olympe de Gouges foi guilhotinada aos 45 anos de idade. Ela teria dito, antes que 
a a sua cabeça fosse decepada, "Filhos da Pátria, vocês vingarão minha morte". O acusador público que a enviou definitivamente para o cadafalso, Antoine Fouquier-Tinville, foi condenado à morte em 1795 por mandar mulheres grávidas para a guilhotina, entre outros crimes. O Reino do Terror durou até o ano de 1794, quando os Jacobinos foram derrotados.

\section{Considerações finais}

Na conclusão de seu artigo "Reinvidicar os direitos das mulheres em 1791: uma tentativa fadada ao fracasso? O interdiscurso da Declaração dos Direitos da Mulher e da Cidadã"115, Jürgen Siess nos fornece um verdadeiro anti-climax: da interrogação proposta no título se reivindicar os direitos das mulheres estaria destinada ao insucesso, ao final ele afirma que tal tentativa está destinada a não ser realizada ${ }^{116}$, devido à existência de homens que simplesmente não querem sequer pensar numa plena igualdade de direitos entre homens e mulheres, muito menos alienarem da sua parcela de poder que possuem. Ora, isso seria deslegitimar totalmente a luta das mulheres atualmente, espelhada no engajamento de Olympe de Gouges à época da Revolução. Ela mesma afirmara com todas as letras na carta À Rainha: "[...] esta obra não seja trabalho de um dia, infelizmente [...] Esta revolução só acontecerá quando todas as mulheres se sensibilizarem com a sua condição deplorável e com os seus direitos que perderam na sociedade" ( $A R, 1791, \mathrm{p} .3)$.

Mesmo sendo moderada politicamente - defendia a queda dos tiranos, mas não a do governo monárquico - e radical - no seu entendimento acerca da relação entre homens e mulheres - o que a tornou "duplamente marginalizada" (SIESS, 2016, p. 159), pensamos que justamente esta dupla margina-

$115 \quad$ Cuja tradução de Rubens Damasceno Morais foi publicada na EID\&A: Revista Eletrônica de Estudos Integrados em Discurso e Argumentação. Ilhéus: UESC, 2016, p. 142-161, e eu devo boa parte da minha argumentação às reflexões suscitadas neste artigo.

116 "Quanto a Olympe de Gouges, diríamos que a autolegitimação destinada a lhe permitir a obtenção de uma posição no espaço público está fadada ao fracasso: ela não poderá ocupar nenhum lugar no campo político" (2016, p. 158). 
lização é o ponto de partida e não a conclusão final de toda a luta das mulheres por seus direitos, já levada a cabo por Olympe no século XVIII. Nesse sentido, olhemos para o exemplo da apropriação e radicalização feita por ela das fontes teóricas que lhe serviram de matriz e fundamento para a sua Declaração e radicalizemos mais ainda, a saber: enfatizar na prática o engajamento no reequilíbrio de poder o qual os homens reservaram histórica e politicamente para si próprios, através de práticas políticas e proposições jurídicas concretas - já tentadas pela girondina, diga-se de passagem - imprescindíveis para as mulheres adquirirem o conhecimento necessário para a defesa de seus interesses na sociedade. ${ }^{117}$ Leiamos o artigo $\mathrm{X}$ da Declaração: "Ninguém deve ser molestado por suas opiniões, mesmo que sejam de princípio; a mulher tem o direito de subir ao cadafalso; mas ela deve igualmente ter o direito de subir à tribuna [...]" (DD, 1971, p. 9).

Para atualizarmos as causas defendidas por Olympe de Gouges, aludimos aqui a um texto chamado "A democracia representativa na ausência de mulheres" de Michèle Riot-Sarcey. A autora, querendo distanciar-se de uma certa tradição francesa que insiste em se gabar quando lembra dos fundadores da democracia liberal, questiona a suposta impossibilidade de aperfeiçoá-la, quando se trata de incluir as mulheres nesse tipo de democracia: "Por espírito de liberdade e por necessidade, considerando a fraquíssima representação das mulheres nas instituições políticas, parece-me indispensável, ao contrário, criticá-lo" (1994, p. 247).

Um dos termos ao qual Riot-Sarcey se atém é o termo igualdade. Palavra pomposa e imponente em termos universais, mas enganosa no sentido particular, a suposta igualdade é, na verdade, uma palavra ilusória que, querendo ser liberadora, só mantém ainda mais os privilégios de quem a manipula, fazendo com que sirva à prática da dominação. Ela cita o exemplo de Jeanne Deroin que, em 1848, já denunciara o vão sentido das palavras e em particular a palavra igualdade, já que esta não

117 E isso o próprio Siess concede, pois “esse é o seu principal traço distintivo, isto é, dar o exemplo a outras mulheres para que elas possam acessar o campo político" (2016, p. 157). 
é inteiramente aplicada nas sociedades (RIOT-SARCEY, 1994, p. 248). Ora, não é sem propósito que ela cita justamente a Olympe de Gouges, que já denunciara essa suposta igualdade entre os sexos quando desnudou as contradições, limites e até mesmo a misoginia da Declaração universal dos direitos do homem, surgida em 1789. E se formos mais a fundo, nos três escritos que escolhemos, podemos ver o quão radical eram no seio da revolução: 1) quando Olympe escreve Zamora et Mirza, peça que inspirou cinco anos depois a redação da Réflexion sur les noirs, ela simplesmente não tinha uma oportunidade igual à dos teatrólogos homens para representar a sua peça, sendo que depois de por vezes revisada por seu tema polêmico - o da abolição da escravatura - pôde ser encenada; 2) quando redige a Declaration des droits de la femme et de la citoyenne, a autora simplesmente mostra que é bastante contraditório escrever acerca dos direitos universais - isto é, que valham igualmente para todos -somente para homens, sendo muito óbvio que o mundo não é constituído somente por homens; 3) por fim, o panfleto Les trois urnes, onde reclama a igualdade de opinião e de peso dos sufrágios na escolha dos governos, incluindo as mulheres nessa escolha democrática a partir da denúncia da tirania jacobina, que não via as mulheres como verdadeiras cidadãs. Esses são somente alguns elementos que, à luz do século XVIII, podemos pensar o lugar, a situação e o papel das mulheres nos regimes democráticos contemporâneos.

Em 2014, o nome de Olympe de Gouges apareceu novamente na cena política nacional francesa, quando escolheram as próximas personalidades da História Francesa que ingressariam no Panthéon, que só contava com os nomes de apenas duas mulheres, Sophie Berthelot e Marie Curie. Foi discutido então o ingresso de mais quatro nomes na cripta do monumento, dentre os quais dois eram de mulheres, Germaine Tillion e Geneviève de Gaulle-Anthonioz. Ambas são conhecidas por seu combate ao nazismo durante a Segunda Guerra Mundial. O nome de Olympe de Gouges foi citado como uma possível candidata à entrada no Panthéon, por sua defesa dos direitos dos negros, das mulheres e dos filhos ilegítimos. Todavia, ela não fez parte dos reconhecidos pela Pátria, e atribui-se esta decisão 
ao momento de instabilidade social que vivia a França, com diversos protestos a favor da família tradicional. Especula-se que ela tenha sido deixada de fora para não ser o estopim de uma reação popular conservadora, visto que suas obras criticavam todos os costumes patriarcais de seu século - século das Luzes! - e, da mesma maneira, os do nosso século. 


\section{Referências:}

ANDRÉ-ANQUIER, Geneviève. Olympe de Gouges et la question de l'esclavage des noirs, Disponível em: http://web.ac-toulouse.fr/automne_modules files/pDocs/public/r26109 61_olympe de gouges et_la_question_de_lesclavage_des_noirs.pdf, acesso em $\overline{2} 6 / \overline{1} 1 / 2019$.

BLANC, Olivier. Olympe de Gouges: des droits de la femme à la guillotine. Paris: Tallandier, 2014.

CRUZ, Amanda de Queirós. Olympe de Gouges: entre o Iluminismo e a guilhotina, "In": Aurora. Niterói: UFF, 2018, ano 1, vol.1, p. 27-38.

CUTRUFELLI, Maria Rosa. Eu vivi por um sonho: os últimos dias de Olympe de Gouges, defensora dos direitos da mulher. Trad. de Maurício Santana Dias. Rio de Janeiro: Record, 2009.

FANON, Frantz. Os condenados da terra. Trad. de Enilce Albergaria Rocha e Lucy Magalhães. Juiz de Fora: Editora UFJF, 2005.

GOUGES, Madame de. Oeuvres. Tome I. Paris: Cailleau, 1788[versão fac-símile].

GOUGES, Olympe de. Les droits de la femme. Paris: s.l.p., 1791.

GOUGES, Olympe de. Déclaration des droits de la femme et de la citoyenne. Paris: s.l.p., 1791.

GOUGES, Olympe de. Réflexions sur les hommes nègres, in: OEuvres de Madame de Gouges, Paris, v. 3, p. 92-99, 1788.

GOUGES, Olympe de. Les trois urnes. Disponível em: https://blogs. bl.uk/european/2013/11/olympe-de-gouges-and-les-trois-urnes. html, acesso em 26/11/2019.

GRASSI, Antonia Criscenti. Olympe de Gouges, Les trois urnes, ou le salut de la patrie (1793), Disponível em: http://www.spaziofilosofico.it/wp-content/uploads/2017/07/Criscenti-Grassi.pdf, acesso em 26/11/2019.

HOLBACH, Barão de. A moral universal ou os deveres do homem fundamentados na sua natureza. Trad. de Regina Schöpke e Mauro Baladi. São Paulo: Martins Fontes, 2014.

JAMES, C.L.R. Os jacobinos negros: Toussaint L'Ouverture e a revolução de São Domingos. Trad. de Afonso Teixeira Filho. São Paulo: Boitempo, 2010.

MULLER, Catel/BOCQUET, José-Louis. Olympe de Gouges. Trad. de André Telles. Rio de Janeiro: Record, 2014.

RIOT-SARCEY, Michèle. A democracia representativa na ausência de mulheres, "In": Estudos feministas. Florianópolis: UFSC, 1994, p. 247-255. 
ROUSSEAU, Jean-Jacques. Discurso sobre a origem e os fundamentos da desigualdade entre os homens. Trad. de Lourdes Santos Machado. São Paulo: Abril Cultural, 1987-88 (Coleção "Os pensadores").

ROUSSEAU, Jean-Jacques. Do contrato social. Trad. de Lourdes Santos Machado. 4 ed. São Paulo: Abril Cultural, 1987 (Coleção "Os Pensadores").

SIESS, Jürgen. Un discours politique au féminin. Le projet d'Olympe de Gouges, "In": Mots. Les langages du politique. Paris: ENS éditions, 2005, 78, p. 9-21.

SIESS, Jürgen. Reivindicar os direitos das mulheres em 1791: tentativa fadada ao fracasso? O interdiscurso da Declaração dos direitos da mulher e da cidadã, trad. de Rubens Damasceno Morais, "In": EID\&A - Revista Eletrônica de Estudos Integrados em Discurso e Argumentação, Ilhéus, n. esp. ADARR, mai. 2016 p. 142-161. 